\title{
Impact of Tax and Fee Reduction on Manufacturing in Dongguan Taking Souyute Group Co., Ltd. as an Example
}

\author{
Yingting Liu ${ }^{1, *}$ Shimin Zhao $^{1}$ Jiaping Zheng ${ }^{1}$ \\ ${ }^{1}$ School of Accountancy, Xinhua College of Sun Yat-Sen University, Guangzhou, Guangdong 510000, China \\ *Corresponding author. Email: 382713919@qq.com
}

\begin{abstract}
In recent years, the state has issued a series of policies related to tax and fee reduction. The promulgation and implementation of these policies are of great significance for the transformation and upgrading of micro-enterprises and have a profound impact. Especially in the context of the global manufacturing industry developing in the direction of intelligence, greening and informatization, the scale and total volume of China's manufacturing industry rank first in the world. However, the gap between China's manufacturing and that of industrial developed countries is large. With the disappearance of the demographic dividend, China's manufacturing industry can no longer continue its labor-intensive path. The major measure of reducing taxes and fees will play a pivotal role in the benefit, efficiency, quality, industrial structure, sustainable development, transformation and upgrading of basic industries such as manufacturing. Taking Souyute Group Co., Ltd. as an example, this paper analyzes the changes and impacts of tax and fee reduction on the company from the perspectives of tax payment costs and financial indicators, proposes relevant suggestions for the development of the company, and finally discusses the enlightenment for the manufacturing companies to promote the implementation of policy dividends and the high-quality development of the company.
\end{abstract}

Keywords: tax and fee reduction, manufacturing, cost of tax payment, financial indicators

\section{INTRODUCTION}

Since 2018, China has successively introduced a series of tax and fee reduction policies, such as the adjustment of tax rate, the raise of threshold, and the adjustment of some business calculation and deduction. The release and implementation of tax and fee reduction policy is of great significance to the transformation and upgrading of micro enterprises. Against the background that global manufacturing industry is developing towards the direction of intelligence, green and information, China's manufacturing industry ranks first in the world in terms of scale and total amount. However, China's manufacturing industry lags far behind that of the United States, Germany, Japan and other industrial developed countries in terms of benefit, efficiency, quality, industrial structure, sustainable development and resource consumption. With the disappearance of demographic dividend, the proportion of the workingage population in the total population will be reduced, and the dependency rate will be higher, which is not

*Fund: This paper is supported by the Innovation and Entrepreneurship Training Plan of College Students in 2018 (201813902034). conducive to creating favorable population conditions for economic development. China's manufacturing industry can no longer follow the labor-intensive road. The major measure of tax and fee reduction plays an important role in the basic industry of manufacturing, such as optimizing the structure, improving the quality of varieties, enhancing the supporting capacity of the industry, eliminating backward production capacity, giving priority to the development of manufacturing industry with advanced equipment, adjusting and optimizing the raw material industry, and upgrading the consumer goods industry.

Most scholars' studies of tax and fee reduction are mainly on theoretical analysis, and a few analyze the impact of tax and fee reduction on logistics enterprises and coal enterprises. However, there are few analyses on the impact of tax and fee reduction policies on the manufacturing industry. After the second session of the 13th National People's Congress on March 15, 2019, in order to better stimulate the competitiveness of the real economy in the market, reducing the value-added tax burden of manufacturing industry and the basic endowment insurance rate of employees in the social security rate has become the focus of the tax and fee 
reduction. For Dongguan, the capital of manufacturing industry, the impact of tax and fee reduction policy, and the promotion for the healthy development of enterprises in light load are of great significance. This paper will focus on a series of reform measures of value-added tax and social security rate. Taking Souyute Group Co., Ltd. as an example, this paper studies the impact of tax and fee reduction on the enterprise, and provides solutions combining with relevant national policies and the specific situation of the enterprise, with a view of providing reference for the better development of the same industry in the context of tax and fee reduction.

\section{CaSe STUdy}

\section{A. Company profile}

1) Basic introduction: Souyute Group Co., Ltd. (formerly known as Dongguan Souyute Clothing Co., Ltd.) was established in Dongguan City, Guangdong Province in December 2005 with the stock code of 002503. "Fashion Front" is a well-known leisure clothing brand of the company, and its operation speed has been stable. In November 2010, Souyute Group was successfully listed on Shenzhen Stock Exchange. With more than 10 billion yuan of assets and more than 2500 employees, Souyute Group has developed into a famous clothing group company in China. Its scope of business is wide, involving many fields such as leisure clothing brand operation, supply chain management, brand management, commercial factoring and foreign investment. Among the "top 500 enterprises in Guangdong in 2019", Souyute Group ranked No. 102. Among the "top 100 private enterprises in Guangdong in 2019", Souyute Group ranked No. 38. In 2018, Souyute Group successfully ranked No. 402 of the top 500 enterprises of China in "Fortune Magazine" for the first time, marking that Souyute Group officially entered the ranks of China's large-scale integrated industry group companies.

2) Tax and fee reduction policy: In recent years, with the implementation of the national tax and fee reduction policy, the company's value-added tax rate has also been reduced from $17 \%$ in 2017 to $16 \%$ on May 1, 2018, and then to $13 \%$ on April 1, 2019. (As shown in the following "Table I")

TABLE I. CHANGE OF THE COMPANY ADAPTING TO TAX RATE

\begin{tabular}{|c|c|c|c|c|}
\hline Year & Categories of taxes & Taxation basis & Tax rate & Remarks \\
\hline 2017 & \multirow[t]{3}{*}{ added-value tax } & \multirow{3}{*}{$\begin{array}{l}\text { According to the tax law, the } \\
\text { substituted money on VAT is } \\
\text { calculated on the basis of the } \\
\text { income from the sale of goods and } \\
\text { taxable services. After deducting } \\
\text { the input VAT allowed to be } \\
\text { deducted in the current period, the } \\
\text { difference is the value-added tax } \\
\text { payable. }\end{array}$} & $17 \%$ & \\
\hline 2018 & & & $17 \% / 16 \%$ & $\begin{array}{l}\text { According to (CS [2018] No. 32), since } \\
\text { May 1, 2018, if the taxpayer has VAT } \\
\text { taxable sales or imported goods, the tax } \\
\text { rates originally applicable to } 17 \% \text { and } \\
11 \% \text { will be reduced to } 16 \% \text { and } 10 \% \\
\text { respectively. }\end{array}$ \\
\hline 2019 & & & $16 \% / 13 \%$ & $\begin{array}{l}\text { Since April } 1,2019 \text {, the state has } \\
\text { reduced the VAT rate of manufacturing } \\
\text { industry from } 16 \% \text { to } 13 \% \text {. }\end{array}$ \\
\hline 2017-2019 & corporate income tax & paying according to taxable income & $25 \%$ & \\
\hline
\end{tabular}

a. Source: annual report data of the company.

As a manufacturing enterprise, Souyute Group can enjoy $75 \%$ additional deduction of $R \& D$ expenses. Since May 1, 2019, the overall pension rate of basic endowment insurance for urban employees will be reduced from $15 \%$ to $14 \%$, and the social insurance payment base will also be reduced. The policy of optimizing the social security rate will bring the negative effect on the labor cost of enterprises, which will directly promote the $R \& D$ and the expansion of investment and financing fields. However, as the annual report of 2019 has not been disclosed, the number of social security employees of the company in 2019 cannot be known, and the impact of social security rate on the company cannot be further analyzed. Therefore, this paper will analyze the impact of tax and fee reduction policy on Souyute Group from the aspect of tax reduction.

\section{B. The influence of tax and fee reduction on Finance}

1) Change of tax payment cost of enterprise: The cost of tax payment can be divided into broad sense and narrow sense. In a broad sense, tax payment cost of enterprise includes tax management cost, tax risk cost, psychological cost and tax entity cost. In a narrow sense, the enterprise tax cost sheet refers to the entity tax paid by the enterprise, that is, the entity tax cost of the enterprise, which refers to various taxes that the enterprise needs to pay to the state in accordance with the provisions of the tax law in production and operation, including turnover tax, income tax and property tax, etc. This case analysis is mainly based on the narrow sense of tax payment cost of enterprise, focusing on the impact of changes in turnover tax and 
income tax such as value-added tax on tax payment cost under the policy of tax and fee reduction.

Value-added tax ranks the first among the taxes, which plays an extremely important role in the tax structure of China. In recent years, from the perspective of tax and fee reduction policies, value-added tax has been mentioned, and the reform efforts have been increased year by year. For manufacturing enterprises that account for nearly $60 \%$ of the total value-added tax, the reduction of value-added tax rate in 2019 is undoubtedly a rain for the long drought. The impact of tax and fee reduction on manufacturing enterprises should be mainly reflected in reducing the value-added tax burden. However, there is still a lack of statistics on the actual payment of value-added tax in the current annual statements of listed companies. At present, the feasible way is to make the reverse deduction of the relevant data of known "taxes and surcharges" to obtain the value-added tax.

In this paper, the value-added tax amount is inverted according to urban maintenance and construction tax / tax rate $(7 \%)$, that is, value-added tax $=$ urban maintenance and construction tax $\div 7 \%$. Then, the proportion of value-added tax amount in operating revenue is taken as the main index to measure the effect of tax reduction. In recent two years, the change time of VAT rate is May 1, 2018 and April 1, 2019. So far, the annual report data of Souyute Group in 2019 has not been published. In this paper, the indicators of the same period (the first half year) for three consecutive years are selected for comparison. The specific data are as follows:

TABLE II. IMPACT OF CHANGES IN VALUE-ADDED TAX FROM THE FIRST HALF OF 2017 TO THE FIRST HALF OF 2019 ON CORPORATE TAX BURDEN (UNIT: 10000 YUAN)

\begin{tabular}{|l|l|l|l|}
\hline Time & $2017 / 1-2017 / 6$ & $2018 / 1-2018 / 6$ & $2019 / 1-2019 / 6$ \\
\hline Urban maintenance and construction tax & $1,684.93$ & $1,799.37$ & 995.78 \\
\hline Added-value tax & $24,070.43$ & $25,705.29$ & $14,225.43$ \\
\hline Operating income & $656,017.98$ & $1,087,984.48$ & $607,704.73$ \\
\hline Tax bearing rate & $3.67 \%$ & $2.36 \%$ & $2.34 \%$ \\
\hline
\end{tabular}

Data source: semiyearly financial report and audit report of the compan

The data in "Table II" shows the payable valueadded tax of Souyute Group from the first half of 2017 to the first half of 2019 and its change trend in each period. It can be seen that the tax reduction effect under the policy of "tax and fee reduction" is gradually clear on the whole, and the tax burden is generally reduced one by one. In the first half of 2019, with the introduction of new policies, the value-added tax rate of manufacturing industry will be reduced from $16 \%$ to $13 \%$, and Souyute Group has the lowest tax burden rate of $2.34 \%$ in the same period of three years for the first time.

However, the author found that in the first half of 2018, the tax burden rate decreased significantly. The VAT tax burden rate is affected by VAT and business income, the growth rate of VAT in the first half of 2018 is about $6.79 \%$, while the growth rate of business income is about $65 \%$. The growth rate of business income is larger than the growth rate of VAT, which shows that the tax rate of Souyute Group in the first half of 2018 decreased not because of the VAT increase but because of the increased operating revenue. The tax and fee reduction policy in 2017 only reduced the VAT tax rate from the fourth level to the third level, the tax rate of $13 \%$ was cancelled. In 2017, the applicable value-added tax rate of Souyute Group was $17 \%$, which had little impact on the tax payment cost of Souyute Group in that year. In the first half of 2018, the tax burden decreased because the growth rate of its business income was greater than that of value-added tax. Therefore, to make better use of the tax and fee reduction policy, enterprises must create more business income as much as possible on the premise that the growth rate of business income is greater than that of value-added tax, so as to reduce the tax burden rate of enterprises.

2) Analysis of financial indicators before and after the implementation of tax and fee reduction: Since the implementation of the policy of reducing fees and taxes, what is the impact on the financial indicators of enterprises? The author analyzes the debt paying ability, operation capacity and profitability.

a) Debt paying ability:According to the urgency of debt repayment, it can be divided into short-term debt repayment ability and long-term debt repayment ability. In this paper, the quick ratio and equity ratio are selected to measure the short-term and long-term debt repayment ability of the enterprise. The quick ratio is the ratio of quick assets to current liabilities, which excludes the influence of inventory and is used to measure the compensation degree of current assets to current liabilities. The larger the quick ratio is, the stronger the debt paying ability of the enterprise is. The equity ratio is the ratio of total liabilities to total shareholders' equity. The lower the ratio is, the stronger the long-term debt repayment ability of the enterprise is, and the less the risk of creditors is. 
TABLE III. CHANGES IN QUICK RATIO AND EQUITY RATIO OF SOUYUTE GROUP AND TEXTILE AND GARMENT INDUSTRY FROM THE FIRST HALF OF 2017 TO THE FIRST HALF OF 2019

\begin{tabular}{|l|l|l|l|l|}
\hline Year & Quick ratio & Industry quick ratio & Equity ratio & Industry equity ratio \\
\hline 2017 semiyearly report & 2.51 & 1.25 & 0.51 & 0.77 \\
\hline 2018 semiyearly report & 1.46 & 1.15 & 0.84 & 0.7 \\
\hline 2019 semiyearly report & 1.18 & 1.08 & 0.97 & 0.73 \\
\hline
\end{tabular}

Data source: Calculation of semiyearly report data of the company

It can be seen from "Table III" that although the quick ratio of Souyute Group in recent three years has declined, it has always been greater than 1 , and higher than the quick ratio in the same industry, which shows that the enterprise's short-term debt paying ability is strong, and the short-term debt paying ability is higher than that in the same industry, which can effectively control the short-term debt paying risk. In addition, the equity ratio of Souyute Group has increased year by year. Compared with the first half of 2017, the equity ratio in the first half of 2018 and the first half of 2019 has increased by $64.7 \%$ and $15.5 \%$ respectively. The equity ratio of Souyute Group in the first half of 2019 is far higher than that of the same industry in the same period, which shows that the enterprise has overused financial leverage, further improved financial risk, weak long-term debt paying ability, and relatively high risk for creditors. The risk that the enterprise undertakes is bigger. The enterprise should adjust its financial structure reasonably and further strengthen the control of long-term debt repayment risk. b) Operation capacity: The operation capacity of an enterprise is determined by the operation capacity of various assets. By analyzing the operation capacity of various assets of an enterprise, the contribution of assets value and the efficiency of assets utilization can be evaluated. This paper uses the turnover rate of accounts receivable and the turnover rate of inventory to evaluate the operation capacity of the enterprise. The turnover rate of accounts receivable refers to the ratio between the net credit sales revenue and the average balance of accounts receivable in a certain period of time, reflecting the speed of turnover of accounts receivable of enterprises. Inventory turnover rate is the ratio of operating cost to average inventory balance. The higher the index is, the faster the inventory liquidation is, the higher the inventory utilization efficiency is, and the stronger the enterprise's profitability is.

TABLE IV. OPERATING CAPACITY CHANGE OF SOUYUTE GROUP AND TEXTILE AND GARMENT INDUSTRY FROM THE FIRST HALF OF 2017 TO THE FIRST HALF OF 2019 (UNIT: \%)

\begin{tabular}{|l|l|l|l|l|}
\hline Year & $\begin{array}{l}\text { Turnover rate of } \\
\text { accounts receivable }\end{array}$ & $\begin{array}{l}\text { Turnover rate of accounts } \\
\text { receivable of industry }\end{array}$ & $\begin{array}{l}\text { Inventory } \\
\text { turnover rate }\end{array}$ & $\begin{array}{l}\text { Inventory turnover rate } \\
\text { of industry }\end{array}$ \\
\hline 2017 semiyearly report & 4.8 & 7.24 & 4.04 & 3.11 \\
\hline 2018 semiyearly report & 6.74 & 6.81 & 4.48 & 3.34 \\
\hline 2019 semiyearly report & 3.32 & 7.51 & 1.79 & 3.12 \\
\hline
\end{tabular}

It can be seen from "Table IV" that the turnover rate of accounts receivable of Souyute Group fluctuates greatly, rising first and then falling, which are generally lower than the level of the same industry. The results show that the recovery speed of accounts receivable of the enterprise is slow, and the utilization efficiency of accounts receivable is low. The change trend of inventory turnover rate is basically the same as that of turnover rate of accounts receivable, which is higher than the level of the same industry in general, indicating that the inventory of this enterprise has a fast cash rate, high utilization efficiency, strong liquidity and good quality of current assets.

c) Profitability: Profitability refers to the ability to earn profits under the normal operating conditions of an enterprise. Net profit margin on sales and net assets income rate are important indicators to reflect the profitability of an enterprise, so this paper only makes a simple analysis of these two indicators. Net profit margin on sales refers to the ratio of net interest rate to net sales, which reflects the final result of enterprise profit. Net assets income rate refers to the ratio of net profit to average shareholders' equity (average net assets), which reflects the investment income of shareholders' equity investment. 
TABLE V. CHANGES IN PROFITABILITY OF SOUYUTE GROUP AND TEXTILE AND GARMENT INDUSTRY FROM THE FIRST HALF OF 2017 TO THE FIRST HALF OF 2019 (UNIT:\%)

\begin{tabular}{|l|l|l|l|l|}
\hline Year & $\begin{array}{l}\text { Net profit } \\
\text { margin on sales }\end{array}$ & $\begin{array}{l}\text { Net profit margin on sales } \\
\text { of industry }\end{array}$ & Net assets income rate & $\begin{array}{l}\text { Net assets income rate } \\
\text { of industry }\end{array}$ \\
\hline 2017 semiyearly report & 6.59 & 9.80 & 6.63 & 9.83 \\
\hline 2018 semiyearly report & 4.61 & 8.16 & 7.91 & 9.1 \\
\hline 2019 semiyearly report & 3.23 & 6.89 & 3.4 & 7.89 \\
\hline
\end{tabular}

It can be seen from "Table V" that the change trend of net profit margin on sales of Souyute Group is generally downward, which is consistent with the change of its industry. In general, the net profit margin on sales of Souyute Group is far lower than that of the same industry, which indicates that the sales profitability of the enterprise is poor. The change trend of net assets income rate of the enterprise is rising first and then declining, and the net assets income rate of the enterprise is lower than the level of the same industry, which shows that the capital profitability of Souyute Group is weak. Especially in the first half of 2019, there is a significant decline.

\section{3) Problems}

a) Decline in operating revenue: In "Table VI", from the first half of 2017 to the first half of 2018, the operating revenue of Souyute Group has been growing. The year-on-year growth rate starts to show a negative growth of $44.14 \%$ in the first half of 2019 . According to the preliminary analysis, Souyute Group is affected by weak market demand and trade friction, and the development speed of its supply chain business is still slowing down. Shaoxing Xinglian, the supply chain subsidiary corporation, has transformed from a holding subsidiary into a joint venture since October, 2018. It was no longer included in the scope of company consolidation, resulting in a significant decline in performance compared with that of the same period of last year.

TABLE VI. CHANGE TREND OF OPERATION REVENUE OF SOUYUTE GROUP FROM THE FIRST HALF OF 2017 TO THE FIRST HALF OF 2019

\begin{tabular}{|l|l|l|l|}
\hline Year & Current operating income (million) & Previous operating income (million) & Year-on-year growth rate (\%) \\
\hline 2017 semiyearly report & $6,560.18$ & $2,286.96$ & 186.85 \\
\hline 2018 semiyearly report & $10,879.84$ & $6,560.18$ & 65.85 \\
\hline 2019 semiyearly report & $6,077.05$ & $10,879.84$ & -44.14 \\
\hline
\end{tabular}

Data source: semiyearly financial report of the company

b) Decrease in cash flow from operating activities: In "Table VII", from the first half of 2017 to the first half of 2019, the cash flow from operating activities of Souyute Group is negative, with a negative growth of 177.34 in the first half of 2017. This is due to the rapid growth of supply chain management business and the substantial increase of revenue, which leads to a substantial increase in taxes paid compared with that of the same period of last year. The increase of factoring loan business leads to a significant increase in net customer loans and advances over the same period of last year. From the first half of 2018 to the first half of 2019 , the year-on-year growth of cash from operating activities showed a positive growth, which was caused by a significant increase in cash received from sales of goods compared with the same period of last year, as well as a decrease in cash paid for the purchase of goods to receive labor services, a decrease in taxes paid, and a decrease in the net increase in advances paid for factoring business. However, the cash flow from operating activities of Souyute Group is negative and lower than the net profit level of the same period, which shows that Souyute Group is difficult to convert the net profit into cash inflow, there is a certain debt repayment risk, and there is uncertainty in the future sustainable profitability.

TABLE VII. NET CASH FLOW FROM OPERATING ACTIVITIES AND NET PROFIT ATTRIBUTABLE TO LISTED SHAREHOLDERS OF SOUYUTE GROUP FROM THE FIRST HALF OF 2017 TO THE FIRST HALF 2019

\begin{tabular}{|l|l|l|l|l|}
\hline Year & $\begin{array}{l}\text { Net cash flow from } \\
\text { current } \\
\text { (million) }\end{array}$ & $\begin{array}{l}\text { Year-on-year } \\
\text { operations }\end{array}$ & $\begin{array}{l}\text { Net profit attributable to shareholders of } \\
\text { growte listed company for the current period } \\
\text { (million) }\end{array}$ & $\begin{array}{l}\text { Year-on-year } \\
\text { growth rate (\%) }\end{array}$ \\
\hline 2017 semiyearly report & -684.17 & -177.34 & 361.05 & 96.38 \\
\hline 2018 semiyearly report & -338.82 & 50.48 & 429.98 & 19.09 \\
\hline 2019 semiyearly report & -172.56 & 49.07 & 185.14 & -56.94 \\
\hline
\end{tabular}




\section{CONCLUSION}

From the analysis of the tax payment cost and financial index data of Souyute Group, the national policy of tax and fee reduction is very strong, and the value-added tax burden rate of Souyute Group has declined. However, the debt paying ability, operation capacity and profitability of the enterprise have not shown the trend of being strengthene, dand the operation situation has not been improved well. The following suggestions are put forward based on the characteristics of manufacturing industry.

\section{A. Actively carrying out effective VAT tax planning and adjustment}

With the decrease of value-added tax rate and the adjustment of relevant tax regulations, the specific content of enterprises in tax planning should also be adjusted to adapt to the current tax laws and regulations. To solve the problem of VAT special invoice, it is required not only to adjust the key and core links of VAT tax rate of invoice according to the new adjustment direction, but also to pay attention to the important problem from general taxpayers to smallscale taxpayers.

\section{B. Adhering to policy orientation and attaching importance to science and technology investment}

This series of tax and fee reduction measures have greatly expanded the applicable types of enterprises and fully reflected the state's support for real enterprises and R \& D. Enterprises should actively adjust the investment structure, make full use of new preferential policies to increase investment in new $\mathrm{R} \& \mathrm{D}$ projects and fields, and actively use preferential policies to adjust and optimize industrial structure. The R \& D cost deduction extends from general technology enterprises to $\mathrm{R} \& \mathrm{D}$ projects of all enterprises, which undoubtedly provides a golden opportunity for the development of manufacturing enterprises. Enterprises should pay more attention to the development and application of scientific and technological innovation projects, use the deduction of $75 \%$ discount of R \& D fee to strive for more scientific research funds and space for enterprises, truly achieve the industrial structure adjustment, promote the practical goal of enterprise development, adapt to the change of market demand, so that enterprises can not only directly benefit from the new tax policy, but also make better use of the savings. The rapid and sustainable development of the enterprise can be realized smoothly. In this way, enterprises can not only enjoy more tax preferences, but also lay a good foundation for the current and future development.

\section{Rebuilding enterprise cooperation mode}

In the new tax system, it not only reduces the tax burden for enterprises directly, but also introduces the important clause of small-scale taxpayer declaration system. This not only applies to small-scale taxpayers, but also directly affects enterprises of all sizes. Although small-scale taxpayers enjoy the ultra-low VAT rate of $3 \%$, they do not have the qualification to issue special VAT invoices, which has a huge impact on most ordinary enterprises that cannot declare smallscale taxpayers. The financial management of an enterprise should also make clear whether it meets the requirements of applying for a general taxpayer and the needs of the enterprise itself, and comprehensively analyze the current enterprise cooperation relationship to determine the appropriate cooperation mode. Once such a change occurs, the financial department should actively analyze the direct impact of such a change on the cooperation and economic activities of the enterprise, and coordinate with the enterprise to adjust and restructure according to the actual needs of the enterprise, so as to ensure that the enterprise enjoys the maximum tax preference and other work and production and operation continue.

\section{Strengthening the training of financial staff}

Enterprises should actively respond to the new tax policies, so that the financial management of enterprises can continue in an orderly manner. And it is also necessary to strengthen the training of financial personnel according to the existing management needs. First of all, financial personnel should be familiar with the specific system and spirit of the new tax law as soon as possible, and face the financial work of enterprises with a more correct and scientific attitude. At the same time, it is necessary to strengthen the learning of relevant knowledge, improve the business ability and avoid the financial management reform from being in trouble due to lack of ability or experience according to the policies required by the enterprise.

\section{References}

[1] Ran Xiaorong. On the impact of tax and fee reduction on enterprises [J]. Shanxi Finance and Taxation, 2019, 483 (05): 48-50. (in Chinese)

[2] Sun Wei. Challenges and Countermeasures of Reducing Enterprise Labor Costs under the New Situation of Tax and Fee Reduction [J]. Sub National Fiscal Research, 2019 (3). (in Chinese)

[3] Li Puliang, Jia Weili. Can "Replacing Business Tax with Valueadded Tax" Spawn Manufacturing Enterprises' Sense of Fulfillment from the Tax Reduction [J]. Journal of Guangdong University of Business Studies, 2019 (1). (in Chinese)

[4] Dong Bijuan. Enterprises apply tax and fee reduction bonuses [N]. Economic Daily, 2019 (009). (in Chinese) 
[5] Qiu Feng, Liang Jiaming. Progress in tax and fee reduction and Its Promotion Path - Based on the Survey of Manufacturing Payments [J]. Qinghai Finance, 2017 (05): 4-8. (in Chinese)

[6] Fan Yong, Li Haonan. A Basic Understanding for the Budern Reduction Effects of the VAT Reform in China [J]. Taxation Research, 2019 (07): 12-18. (in Chinese) 